\title{
Faktor yang Mempengaruhi Minat Beli Roti Halal pada Mahasiswa Muslim
}

\author{
Fauziyyah Hanum ${ }^{1}$, Adityawarman ${ }^{2}$ \\ Universitas Diponegoro', Universitas Diponegoro' ${ }^{2}$ \\ fauziyyah15@gmail.com ${ }^{1}$, Ade.adityawarman@gmail.com²
}

\begin{abstract}
Public consumption of bread has increased because bread is considered practical, easy to find, and can be consumed at any time so that makes buying interest in bread continues to increase. However, bread has a critical point in the additional ingredients used in making bread so that its halalness is still in doubt. Based on this phenomenon, the purpose of this study is to find out the factors that influence the buying interest of Muslim Consumers in halal bread products. This research uses a quantitative method with Multiple Linear Regression analysis which is assisted by using SPSS software version 23. Independent variables in this study are halal awareness, halal certification, religiosity, halal marketing, and personal social perception. While the dependent variable is purchase intention. Data obtained through a questionnaire distributed to 100 Muslim students of the Faculty of Economic and Busines, Diponegoro University, Semarang. The results of the study showed that halal awareness, halal certification, religiosity, halal marketing, and personal social perception affected the purchase intention of halal bread positively and significantly.

Keywords: Halal Bread, Halal Marketing and Halal Certification
\end{abstract}

\begin{abstract}
Abstrak
Konsumsi masyarakat akan roti mengalami peningkatan karena roti dinilai praktis, mudah ditemukan, dan dapat dikonsumsi di segala waktu sehingga membuat minat beli akan roti terus meningkat. Akan tetapi, roti memiliki titik kritis keharaman pada bahan tambahan yang digunakan dalam pembuatan roti sehingga kehalalannya masih diragukan. Berdasarkan fenomena tersebut, maka tujuan dari penelitian ini yaitu untuk mengetahui faktor yang mempengaruhi minat beli konsumen muslim pada produk roti halal. Penelitian ini memakai metode kuantitatif dengan analisis Regresi Linier Berganda yang dibantu dengan menggunakan software SPSS versi 23. Variabel independen pada penelitian ini yaitu kesadaran halal, sertifikasi halal, religiusitas, pemasaran halal, dan persepsi sosial pribadi. Sedangkan variabel dependen yaitu minat beli. Data diperoleh melalui kuesioner yang disebar ke 100 mahasiswa muslim Fakultas Ekonomika dan Bisnis Universitas Diponegoro Semarang. Hasil penelitian menunjukkan bahwa kesadaran halal, sertifikasi halal, religiusitas, pemasaran halal, dan persepsi halal berpengaruh terhadap minat beli roti halal secara positif dan signifikan.
\end{abstract}

Kata Kunci: Roti Halal, Pemasaran Halal dan Sertifikasi Halal

\section{PENDAHULUAN}

Indonesia menjadi negara dengan penduduk muslim terbesar di dunia. Menurut The Future of the Global Muslim Population (2011) mendata jika jumlah penduduk Indonesia yang beragama Islam sebesar 204.847.000 jiwa. Banyaknya jumlah penduduk muslim di Indonesia membuat pasar industri 
halal mulai berkembang dan tingkat konsumsi makanan halal meningkat di masyarakat.

Dalam Islam konsumsi bukan hanya sebagai pemenuhan keinginan saja, tetapi juga untuk mencapai suatu maslahah dala hidupnya. Dalam agama Islam mengajarkan seorang muslim haruslah mengonsumsi segala sesuatu yang halal dan juga thoyyib. Selain itu juga umat muslim diperintahkan untuk menjauhi segala sesuatu yang haram dan syubhat.

Dalam surat Al-Baqarah ayat 168, Allah Subhanahu wa Ta'ala berfirman:

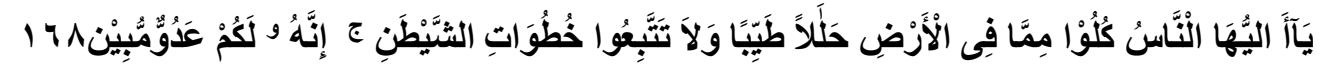
Artinya: "Hai sekalian mausia, makanlah makanan yang halal lagi thoyyib dari apa yang ada di muka bumi, dan janganlah Engkau mengikuti langkahlangkah syaitan; karena sesungguhnya syaitan itu merupakan musuh yang nyata bagimu." (Qs. Al-Baqarah : 168)

Ayat tersebut menjelaskan bahwasannya Allah telah memberi perintah kepada seluruh umatnya yang ada di bumi ini untuk mencari dan mengonsumsi makanan serta minuman yang halal dan thoyyib serta bermanfaat dan tidak mengandung hal-hal yang berbahaya bagi dirinya. Oleh karena itu, setiap umat muslim diwajibkan mengonsumsi makan dan minum yang telah ditetapkan oleh Allah Subhanahu wa Ta'alla dan melarang seluruh umatnya untuk megonsumsi makanan dan minuman yang diharamkan.

Di zaman yang semakin berkembang, membuat segala sesuatu yang dilarang atau haram menjadi sulit dibedakan termasuk dalam hal makanan maupun minuman. Tekonologi pangan yang semakin berkembang membuat produk pangan yang beredar di masyarakat menjadi sulit dibedakan halal dan haramnya. Oleh sebab itu, sebagai umat muslim kita dituntut untuk menjaga diri dari segala hal yang syubhat atau yang masih samar-samar.

\section{Gambar 1}

\section{Rata-Rata Pengeluaran per Kapita Sebulan di Daerah Perkotaan Menurut Kelompok Barang dan Golongan Pengeluaran per Kapita} Sebulan (2013-2017)

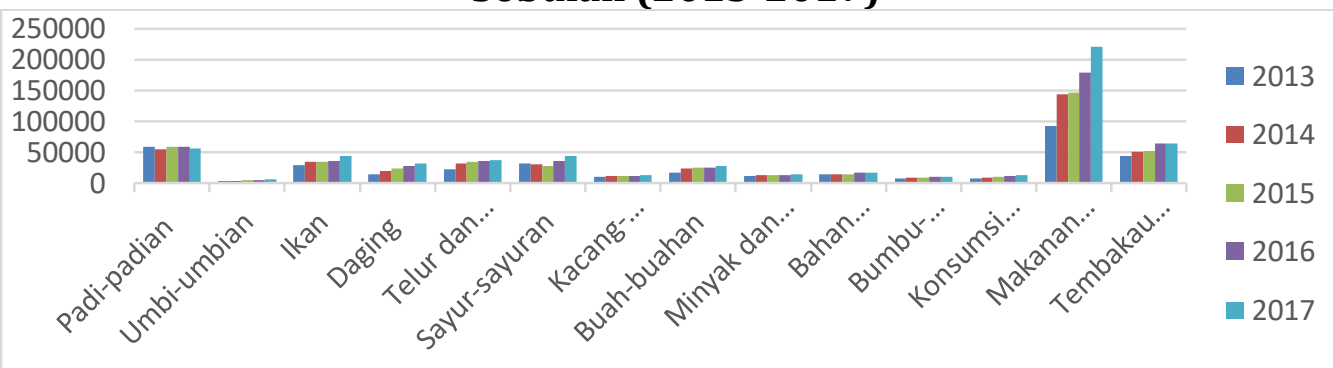

Sumber: Susenas, Badan Pusat Statistika (2017) Data diolah 2019

Gambar 1 menunjukkan bahwa pola konsumsi pangan yang ada di masyarakat saat ini telah mengalami perubahan dari padi-padian atau beras mulai beralih ke makanan dan minuman jadi. Makanan yang tergolong makanan dan minuman jadi adalah roti, mie instan, makanan beku, sereal 
dan lain sebagainya. Pada tahun 2017 tingkat konsumsi makanan dan minuman jadi di masyarakat Indonesia telah terjadi kenaikan yang signifikan dengan rata-rata per kapita sebesar Rp 220.882 per bulan. Hal ini disebabkan oleh tingginya aktivitas yang mereka jalani setiap harinya. Salah satu makanan olahan yang sering dikonsumsi adalah roti. Roti dipilih karena dinilai praktis, mengandung kabohirdat dan memiliki nilai yang yang tinggi, dan dapat disajikan dengan berbagai macam rasa (Joko M. dalam Muliasari \& Rachmina, 2013).

Setyo \& Yulianti (2004) mendefinisikan roti sebagai salah satu produk pangan dibuat dari adonan tepung terigu dan ragi yang difermentasi lalu diolah dengan cara dipanggang. Jenis roti yang saat ini beredar di masyarakat sangatlah bermacam-macam, namun secara umum ada tiga jenis roti yang beredar di masyarakat, yaitu roti tawar, roti manis, dan roti isi. Segmentasi pasar juga sangatlah luas di mana roti dapat dikonsumsi dari segala kalangan maupun usia (Saputra, 2014)

Bahan-bahan yang dipakai untuk membuat roti tidak hanya tepung terigu, ragi, telur, dan air saja, akan tetapi ada beberapa bahan tambahan yang digunakan agar menghasilkan roti yang empuk dan enak. Menurut Halal MUI (2014), bahan tambahan yang digunakan dalam pembuatan roti memiliki beberapa titik kritis kehalalan yang kandungannya tergolong syubhat atau masih diragukan. Contohnya, penggunaan Rhum dalam campuran pembuatan adonan roti. Rhum biasanya digunakan untuk membuat adoanan tercampur dengan baik sehingga cake lebih awet dan juga membuat aroama lebih terikat. Rhum adalah bahan tambahan roti yang mengandung khamer atau alkohol di mana kandungan alkohol dalam rhum bisa mencapai 38-40\%.

Semarang adalah Ibu Kota Jawa Tengah yang memiliki jumlah penduduk sebesar 1.815.729 jiwa yang mana mayoritas masyarakat Kota Semarang beragama Islam dengan jumlah sebesar 1.350 .310 jiwa (BPS, 2018). Saat ini Kota Semarang banyak beredar merek-merek roti yang menawarkan produknya dengan berbagai macam varian bentuk dan rasa. Akan tetapi, dari sekian banyaknya produk roti yang beredar di Kota Semarang, masih ada beberapa merek roti yang belum bersertifikat halal. Tahun 2014, LPPOM MUI mendata baru ada sekitar 304 produk dan bahan roti yang telah dinyatakan halal oleh MUI (Republika, 2014). Hal itu tentu merugikan konsumen yang berasal dari umat muslim, karena konsumen tidak memperoleh kejelasan mengenai kehalalan produk yang akan mereka beli dan bisa mempengaruhi minat beli mereka terhadap produk roti.

Bedasarkan latar belakang tersebut, masyarakat muslim dalam mengonsumsi roti haruslah lebih berhati-hati. Pada saat akan membeli suatu produk makanan terutama produk roti, sertifikasi halal adalah urgensi terpenting menurut konsumen untuk menjamin produk yang akan dikonsumsi aman bagi seluruh konsumen.

Penelitian ini ingin mengembangkan penelitian terdahulu yang berkaitan terhadap faktor yang mempengaruhi minat beli konsumen muslim. Penelitian yang telah dilakukan oleh Awan, et al (2015) dengan judul Factors 
Affecting Halal Purchase Intention-Evidence from Pakistan's Halal Food Sector menyebutkan bahwa kesadaran halal masyarakat muslim Pakistan tidak memiliki pengaruh yang positif pada minat beli. Hal ini tentu saja bertentangan dengan penelitian yang dilaksanakan oleh Putri \& Rimadias (2019) dengan judul Analisis Aspek Penentu Niat Konsumen dalam Membeli Produk Halal di Indonesia (Telaah pada Mie Ramen Jepang Halal) yang mana menyatakan bahwa kesadaran halal berpengaruh secara positif pada minat beli.

Penelitian Awan, et al (2015) menyebutkan kalau sertifikasi halal memiliki pengaruh yang positif pada minat beli. Hal ini bertentangan dengan penelitian yang telah dilakukan oleh Nurhasanah, et al (2018) yang berjudul Faktor-Faktor yang Mempengaruhi Minat Beli Produk Makanan Olahan Halal yang menyatakan bahwa sertifikasi halal tidak berpengaruh signifikan terhadap minat beli. Produsen dalam menjual produknya diperlukan sebuah strategi pemasaran agar konsumen mengetahui produk yang ditawarkan dan menarik minat beli mereka terhadap produk yang dijual. Kajian yang telah dilakukan oleh Awan, et al (2015) menyebutkan jika pemasaran halal berpengaruh secara positif pada minat beli. Hal ini bertentangan dengan penelitian yang juga dilaukan oleh Faturohman (2019) serta Putri dan Rimadias (2019) yang mana hasil penelitian tersebut menunjukkan kalau pemasaran halal tidak pengaruh positif pada minat beli.

Awan, et al (2015) dalam penelitiannya menunjukkan bahwa religiusitas dan persepsi sosial pribadi berpengaruh positif pada minat beli konsumen muslim. Berdasarkan perbedaan hasil dari penelitian-penelitian tersebut maka perlu dilakukan penelitian ulang yang lebih mendalam mengenai faktor-faktor yang bisa mempengaruhi minat beli konsumen muslim akan roti halal.

Adapun variabel yang diuji untuk dijadikan variabel yang bisa mempengaruhi minat beli produk roti halal adalah kesadaran halal, sertifikasi halal, religiusitas, pemasaran halal, dan persepsi sosial pribadi. Pengamatan akan dilakukan pada salah satu makanan pengganti yang sering dikonsumsi masyarakat Semarang yaitu roti. Penelitian ini terbatas pada mahasiswa muslim FEB Universitas Diponegoro Semarang yang pernah membeli dan mengonsumsi produk roti.

Berdasarkan penjelasan diatas, maka pertanyaan ini adalah apakah kesadaran halal, sertifikasi halal, religiusitas, pemasaran halal, dan persepsi sosial pribadi berpengaruh terhadap minat beli konsumen pada produk roti halal.

\section{KAJIAN PUSTAKA}

\section{Teori Perilaku Terencana (Theory of Planned Behavior)}

Teori Perilaku Terencana adalah intensi atau niat seseorang untuk melaksanakan tindakan ataupun perilaku yang tertentu (Ajzen, 1991 dalam Achmat, 2015). Theory of Planned Behavior (TPB) berdasarkan dari anggapan jika manusia merupakan makhluk yang rasional yang memakai informasi 
yang diperoleh dan memungkinkan bagi dirinya secara sistematis. Tujuan dan manfaat dari TPB yaitu untuk mengetahui serta memahami efek motivasional terhadap perilaku yang tidak termasuk di bawah kontrol atau kemauan individu itu sendiri (Mahyarni, 2013). Theory of Plannned Behavior menggunakan 3 (tiga) konstruk sebagai antaseden dari intensi, yaitu sikap, norma subjektif, dan persepsi kontrol perilaku.

\section{Perilaku Konsumen}

Kotler dan Keller (2009) mengartikan perilaku konsumen sebagai kajian mengenai bagaiamana cara seseorang, kelompok, dan organisasi menyeleksi, membeli, memakai barang, jasa, ide, maupun pengalaman untuk memenuhi kepentingan dan keinginan mereka. Ada beberapa faktor yang mempenagruhi perilaku konsumen, yaitu faktor budaya, faktor sosial, faktor pribadi, maupun faktor psikologi.

\section{Minat Beli}

Assael (dalam Susanto \& Rahmi, 2013) mengartikan minat beli sebagai langkah terakhir dari sebuah prosedur keputusan pembelian yang kompleks di mana tahap ini diawali dengan munculnya kebutuhan akan sebuah komoditas atas nama (need arousal) yang kemudian dilanjutkan dengan memproses pengetahuan dari konsumen (consumer information processing) lalu konsumen akan mengevaluasi produk atau nama brand tersebut. Hasil dari evaluasi inilah yang kemudian memunculkan sebuah intensi (niat) untuk membeli sebelum akhirnya konsumen yakin untuk melakukan pembelian.

\section{Kesadaran Halal}

Kesadaran halal adalah pengertian mengenai paham atau tidak pahamnya seorang muslim mengenai halal, mengetahui metode yang benar berdasarkan syariat Islam, dan mengutamkan makanan halal untuk dikonsumsi (Azam, 2016).

\section{Sertifikasi Halal}

Sertifikasi halal merupakan sebuah jaminan perlindungan terhadap seluruh konsumen terutama konsumen muslim untuk bisa memastikan makananannya baik dan sesuai dengan regulasi yang ada. Sertifikat halal akan diberikan kepada produsen atau perusahaan apabila produk tersebut telah lulus uji halal dari MUI.

\section{Religiusitas}

Keyakinan agama atau religiusitas adalah sebuah bentuk hubungan antara manusia dengan pencipta-Nya lewat ajaran agama yang telah tertanam pada diri seseorang yang tercermin ke dalam sikap serta perilakunya sehari-hari. Religiusitas juga menunjukkan bagaimana seseorang berkomitmen terhadap agama yang dianut dan hal itu merupakan bentuk cerminan dalam sikap dan perilakunya. 


\section{Pemasaran Halal}

Pemasaran halal adalah proses sosial dimana individu mau pun kelompok mendapatkan apa saja yang dibutuhkan dan diinginkan mereka melalui penciptaan, penawaran, dan pertukaran barang atau pun jasa yang mempunyai nilai tertentu terhadap individu maupun kelompok lain sesuai dengan kaidah serta tuntutan yang telah diatur di dalam syari'at Islam.

\section{Persepsi Sosial Pribadi}

Persepsi adalah sebuah cara bagaimana seseorang memilih, mengatur, serta menganalisis input-input informasi agar dapat menciptakan gambaran keseluruhan makna (Kotler, 1993 dalam Nurcahyo \& Hudrasyah, 2017). Persepsi diartikan sebagai proses pengkategorian dan interpretasi individu menjadi lebih selektif (Putri \& Rimadias, 2019). Faktor yang mempengaruhi persepsi seseorang adalah karakteristik dan faktor situasional. Standar yang subyektif memungkinkan untuk memiliki efek yang lebih kuat pada tujuan pembelian makanan halal (Nurcahyo \& Hudrasyah, 2017).

\section{Kerangka Penelitian}

\section{Gambar 3}

Kerangka Pemikiran

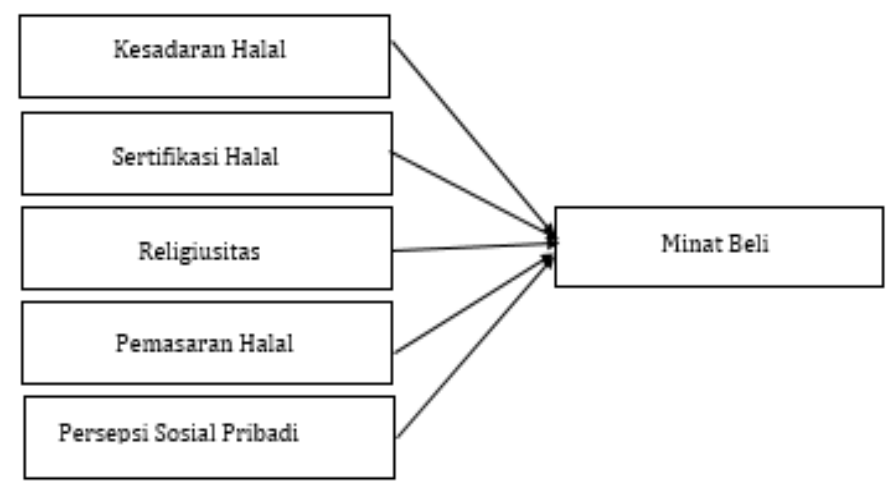

Sumber: Muhammad Hayat Awan, Nabeel Assidiquei, Zeeshan Haider (2015)

\section{Hipotesis}

Berdasarkan pada rumusan masalah, landasan teoritis, dan kerangka pemikiran yang dipakai, maka hipotesis yang diajukan pada penelitian ini adalah:

H1: Kesadaran halal berpengaruh positif terhadap minat beli produk roti halal.

H2: Sertifikasi halal berpengaruh positif terhadap minat beli produk roti halal.

H3: Religiusitas berpengaruh positif terhadap minat beli produk roti halal. H4: Pemasaran halal berpengaruh positif terhadap minat beli produk roti 
Faktor yang Mempengaruhi Minat Beli Roti Halal pada Mahasiswa Muslim

halal.

H5: Persepsi sosial pribadi berpengaruh positif terhadap minat beli produk roti halal.

\section{METODE PENELITIAN}

Pada penelitian ini, populasi yang digunakan yaitu mahasiswa muslim FEB Universitas Diponegoro Semarang. Teknik pengambilan sampel yang dipakai yaitu non-probability sampling dengan purposive sampling sebagai metodenya. Pertimbangan sampel pada penelitian ini adalah mahasiswa FEB Universitas Diponegoro Semarang, Mahasiswa beragama Islam, dan pernah mengonsumsi produk roti. Sampel penelitian ini berjumlah 100 responden.

Variabel bebas penelitian ini ada 5, yaitu kesadaran halal, sertifikasi halal, religiusitas, pemasaran halal, dan persepsi sosial pribadi. Sedangkan variabel terikat yang digunakan ada 1, yaitu minat beli. Selain itu, terdapat 24 indikator yang harus diisi oleh responden. Pengumpulan data menggunakan metode dengan cara observasi, kuesioner, dan kepustakaan. Kuesioner disebar secara online melalui google form dengan skala yang dipakai adalah skala likert. Sugiyono (2014) mendefiniskan skala likert sebagai skala pengukuran yang dipakai untuk menilai sebuah sikap, pendapat, dan persepsi seseorang atau sekelompok orang berkenaan dengan fenomena sosial. Rentang nilai yang digunakan adalah 1-5 dengan jawaban sangat tidak setuju (STS), tidak setuju (TS), netral (N), setuju (S), dan sangat setuju (SS).

Analisis deskriptif dan analisis kuantitatif adalah analisis yang dipakai pada penelitian ini. Tujuan dari analisis deskriptif adalah untuk mendapatkan perkiraan tentang jawaban responden terhadap pertanyaan-pertanyaan yang menjadi instrumen dalam penelitian ini. Perhitungan pada analisis deskriptif menggunakan three box method. Analisis kuantitatif memakai uji instrumen yang terdiri dari uji validitas dan uji reliabilitas, uji asumsi klasik, analisis regresi berganda, dan pengujian hipotesis seperti koefisien determinasi, uji F, dan uji T. Sedangkan alat analisis yang dipakai untuk mengolah data dan analsisis statistik yaitu software SPSS versi 23.

\section{HASIL DAN PEMBAHASAN}

\section{Gambaran Umum Objek Penelitian}

Roti adalah salah satu bahan makanan pokok yang diolah dari adonan tepung terigu dan juga air yang difermentasikan menggunakan ragi. Di Indonesia, budaya mengonsumsi roti dipengaruhi oleh Belanda di mana Belanda memperkenalkan roti dengan cara diperjual belikan kepada penduduk pribumi. Selain itu, mengonsumsi roti pada zaman kolonial juga dianggap sebagai penentu status sosial di masyarakat. Tahun demi tahun roti mulai mengalami perkembangan yang sangat signifikan di mana kini roti memiliki berbagai macam bentuk dengan rasa dan isi yang bermacam-macam. Akan tetapi, ternyata roti mempunyai titik kritis keharaman yang tergolong syubhat atau masih diragukan kehalalannya, sehingga perlu dilakukan pengujian akan kandungan halal yang ada pada produk roti. Berikut adalah 
beberapa merek roti yang ada di Kota Semarang telah memiliki sertifikat halal maupun yang belum memiliki sertifikat halal.

Tabel 2

Daftar Merek Roti Bersertifikat Halal

\begin{tabular}{l|c|c}
\hline \multicolumn{1}{c|}{ Merek Roti } & Nomor Sertifikat Halal & $\begin{array}{c}\text { Masa Berlaku } \\
\text { Sertifikat Halal }\end{array}$ \\
\hline SR & 00200009241298 & 31 Juli 2020 \\
\hline SHB & 15200000670207 & 19 April 2020 \\
\hline MRB & 00200042101006 & 15 Mei 2020 \\
\hline VB & 15100001900608 & - \\
\hline HB & 00160083100517 & 14 Mei 2021 \\
\hline JD & - & - \\
\hline FB & - & - \\
\hline BT & - & - \\
\hline RB & 15200034421018 & 12 Oktober 2020 \\
\hline BL & 00160079891116 & 17 April 2021
\end{tabular}

Sumber: LPPOM MUI, diolah 2019

Tabel 2 menunjukkan bahwa roti dengan merek SR, SHB, MRB, HB, RB, dan BL telah mempunyai sertifikasi halal dengan masa berlaku sertifikat yang jelas. Merek roti VB telah memiliki sertifikat halal akan tetapi masa berlaku sertifikat halal tidak diketahui. Sedangkan merek roti FB, JD, dan BT sampai saat ini belum mendaftarkan produknya ke LPPOM MUI karena nomor sertifikat halal tidak diketahui baik itu di website resmi MUI maupun informasi yang dicantumkan pada produk itu sendiri.

\section{Analisis Deskriptif}

Analisis deskriptif ini menggunakan analisis indeks skala 1 sampai 5 dengan perhitungan three box method untuk mendapatkan penilaian responden terhadapa jawabannya pada masing-masing variabel (Ferdinand, 2006). Dengan perhitungan batas antara atas dan bawah rentang, angka indeks yang diperoleh adalah 20 sampai 100 dengan rentang 80 dan rentang tersebut dibagi menjadi 3 bagian sehingga hasil rentang yang yang diperoleh untuk masing-masing bagian adalah 26,67. Berikut adalah beberapa kategori jawabana respond:
a. $20,00-46,67$ : Rendah
b. $46,68-73,33$ : Sedang
c. 73,34-100,0 : Tinggi

Hasil dari analisis deskriptif yang telah dilakukan pada setiap variabel menunjukkan bahwa variabel kesadaran halal, sertifikasi halal, religiusitas, pemasaran halal, persepsi sosial pribadi, dan minat beli memiliki indeks tinggi. Variabel dengan indeks tertinggi ditunjukkan oleh variabel kesadaran halal. 
Faktor yang Mempengaruhi Minat Beli Roti Halal pada Mahasiswa Muslim

\section{Analisis Kuantitatif \\ Uji Validitas}

Uji validitas dipakai untuk menilai valid atau tidak valid sebuah kuesioner. Indikator dinyatakan valid bial $r$ hitung $\geq r$ tabel atau tingkat signifikannya di bawah 0,05. Pada penelitian ini, $r$ tabel yang diperoleh sebesar 0,1638. Dari hasil uji validitas yang telah dilakukan, bisa diketahui kalau semua item kuesioner memperoleh nilai $r$ hitung lebih besar dari $r$ tabel dan juga nilai signifikansi yang diperoleh dari semua variabel $\leq 0,05$ jadi bisa dinsimpulkan jika seluruh indikator pada penelitian ini valid.

\section{Uji Reliabilitas}

Uji reliabilitas pada penelitian ini memakai rumus Cronbach Alpha. Variabel dengan nilai cronbach alpha $\geq 0,6$ dapat dinyatakan bahwa variabel tersebut reliabel (Ghozali, 2011). Berdasarkan uji reliabilitas, diperoleh hasil perhitungan dari masing-masing variabel yaitu kesadaran halal 0,833, sertifikasi halal 0,773 , religiusitas 0,830 , pemasaran halal 0,825 , persepsi sosial pribadi 0,782 , dan minat beli 0.842 di mana cronvbach alphanya lebih dari 0,6. Jadi seluruh variabel pada penelitian ini dinyatakan reliabel.

\section{Uji Asumsi Klasik}

\section{Uji Normalitas}

Uji normalitas pada penelitian ini melihat hasil dari uji Kolmogrov-Smirnov. Hasil dari uji Kolmogrov Smirnov pada penelitian ini menghasilkan nilai sebesar 0,068 yang membuktikan jika semua variabel pada penelitian ini terdistribusi secara normal.

\section{Uji Multikolinearitas}

Hasil dari uji multikolinearitas dapat dilihat melalui nilai Tollerance dan Variance Inflation Factor (VIF). Variabel dinyatakan terbebas multikolinearitas jika nilai Tollerance lebh dari 0,1 dan nilai VIF kurang dari 10. Dari hasil uji yang telah dilaksanakan, tabel 3 menunjukkan bahwa data penelitian tidak terjadi gejala multikolinearitas.

\section{Tabel 3}

Hasil Uji Multikolinearitas

\begin{tabular}{|c|c|c|c|}
\hline \multirow[t]{2}{*}{ Variabel } & \multicolumn{2}{|c|}{ Collinearity Statistics } & \multirow[t]{2}{*}{ Keterangan } \\
\hline & Tollerance & VIF & \\
\hline Kesadaran Halal & 0,930 & 1,075 & $\begin{array}{l}\text { Tidak timbul } \\
\text { gejala } \\
\text { multikolinearitas }\end{array}$ \\
\hline Sertifikasi Halal & 0,901 & 1,109 & $\begin{array}{l}\text { Tidak timbul } \\
\text { gejala } \\
\text { multikolinearitas }\end{array}$ \\
\hline Religiusitas & 0,871 & 1,148 & $\begin{array}{l}\text { Tidak timbul } \\
\text { gejala }\end{array}$ \\
\hline
\end{tabular}




\begin{tabular}{|c|c|c|c|}
\hline & & & multikolinearitas \\
\hline Pemasaran Halal & 0,919 & 1,088 & $\begin{array}{l}\text { Tidak timbul } \\
\text { gejala } \\
\text { multikolinearitas }\end{array}$ \\
\hline $\begin{array}{l}\text { Persepsi } \\
\text { Pribadi }\end{array}$ & 0,936 & 1,069 & $\begin{array}{l}\text { Tidak timbul } \\
\text { gejala } \\
\text { multikolinearitas }\end{array}$ \\
\hline
\end{tabular}

Sumber: Data hasil olahan penulis, 2019

\section{Uji Heteroskedastisitas}

Uji heteroskedastisitas yang telah dilakukan pada penelitian ini bertujuan untuk mengetahui apakah pada model regresi ada ketidaksamaan variance dan faktor residual dari satu pengamatan ke pengamatan lainnya. Scatterplot digunakan untuk melihat ada atau tidaknya gejala heteroskedastisitas. Pada penelitian ini hasil dari uji yang telah dilakukan membuktikan kalau model regresi pada penelitian ini tidak timbul gejala heteroskedastisitas karena titik-titik tersebar secara acak baik di atas maupun di bawah angka 0 pada sumbu Y.

\section{Uji Autokorelasi}

Uji autokorelasi bisa dilihat dengan melakukan uji Durbin-Watson pada model regresi. Hasil dari uji autokorelasi menunjukkan tidak ditemukan masalah autokorelasi sebab nilai $\mathrm{D}-\mathrm{W}$ berada pada kondisi $\mathrm{dU}<\mathrm{d}<4$-dU.

\section{Analisis Regresi Linier Berganda}

\section{Tabel 4}

Hasil Uji Analisis Regresi Linier Berganda

\begin{tabular}{|c|c|c|c|c|c|}
\hline \multirow{2}{*}{ Model } & \multicolumn{2}{|c|}{$\begin{array}{l}\text { Unstandardized } \\
\text { Coefficients }\end{array}$} & \multirow{2}{*}{$\begin{array}{c}\begin{array}{c}\text { Standardize } \\
\text { d } \\
\text { Coefficients }\end{array} \\
\text { Beta }\end{array}$} & \multirow{2}{*}{$\mathbf{T}$} & \multirow{2}{*}{ Sig. } \\
\hline & B & $\begin{array}{c}\text { Std. } \\
\text { Error }\end{array}$ & & & \\
\hline 1 (Constant) & $-4,178$ & 2,540 & & $-1,645$ & 0,103 \\
\hline $\mathrm{KH}$ & 0,314 & 0,067 & 0,364 & 4,682 & 0,000 \\
\hline $\mathrm{SH}$ & 0,238 & 0,079 & 0,239 & 3,027 & 0,003 \\
\hline $\mathrm{R}$ & 0,205 & 0,069 & 0,239 & 2,967 & 0,004 \\
\hline $\mathrm{PH}$ & 0,340 & 0,062 & 0,426 & 5,439 & 0,000 \\
\hline PSP & 0,157 & 0,069 & 0,177 & 2,278 & 0,025 \\
\hline
\end{tabular}

Sumber: Data hasil olahan penulis. 2019

Berdasarkan hasil uji regresi berganda yang telah dilakukan, hasil persamaan dari regresi linier berganda, yaitu:

$$
\text { Minat Beli }=0,364 \mathrm{X} 1+0,239 \mathrm{X} 2+0,239 \mathrm{X} 3+0,426 \mathrm{X} 4+0,177 \mathrm{X} 5+\mathrm{e}
$$


Faktor yang Mempengaruhi Minat Beli Roti Halal pada Mahasiswa Muslim

\section{Uji Hipotesis}

\section{Koefisien Determinasi}

Uji koefisien determinasi yang telah dilakukan menunjukkan bahwa nilai adjusted $R^{2}$ yang diperoleh pada penelitian ini adalah 0,443 atau $44,3 \%$. Hal ini menunjukkan bahwa sebesar 44,3\% minat beli roti halal dipengaruhi oleh 5 variabel independen yaitu kesadaran halal, sertifikasi halal, religiusitas, pemasaran halal, dan persepsi sosial pribadi. Sedangkan sisanya yaitu 55,7\% minat beli terhadap roti halal dipengaruhi oleh variabel lain yang tidak diteliti pada penelitian ini.

\section{Uji F}

Uji $\mathrm{F}$ pada penelitian ini bertujuan untuk melihat apakah variabel bebas secara bersamaan mempunyai pengaruh pada varaiabel terikat (Ghozali, 2013). Berdasarkan perhitungan tabel $F$, diperoleh $F$ tabel sebesar 2,31 . Nilai Fhitung 16,742 > F tabel 2,31 dan nilai sig. < 0,05. Berdasarkan hasil penelitian dapat disimpulkan bahwa variabel kesadaran halal, sertifikasi halal, religiusitas, pemasaran halal, dan persepsi sosial pribadi secara bersama-sama dapat mempengaruhi minat beli secara simultan.

\section{Uji T}

Tabel 9

Hasil Uji T

Coefficients $^{\mathrm{a}}$

\begin{tabular}{|c|c|c|c|c|c|c|}
\hline & & \multicolumn{2}{|c|}{$\begin{array}{l}\text { Unstandardized } \\
\text { Coefficients }\end{array}$} & \multirow{2}{*}{$\begin{array}{c}\text { Standardize } \\
\mathrm{d} \\
\text { Coefficients }\end{array}$} & \multirow[b]{2}{*}{$\mathrm{t}$} & \multirow[b]{2}{*}{ Sig. } \\
\hline \multicolumn{2}{|c|}{ Model } & $\mathrm{B}$ & Std. Error & & & \\
\hline \multirow[t]{6}{*}{1} & (Constant) & -4.178 & 2.540 & & -1.645 & .103 \\
\hline & TOTAL_KH & .314 & .067 & .364 & 4.682 & .000 \\
\hline & TOTAL_SH & .238 & .079 & .239 & 3.027 & .003 \\
\hline & TOTAL_R & .205 & .069 & .239 & 2.967 & .004 \\
\hline & TOTAL_PH & .340 & .062 & .426 & 5.439 & .000 \\
\hline & TOTAL_PSP & .157 & .069 & .177 & 2.278 & .025 \\
\hline
\end{tabular}

Sumber: Data hasil olahan penulis, 2019

Berikut adalah hasil dari uji $\mathrm{T}$ yang diperoleh untuk tiap-tiap variabel independen, sebagai berikut:

\section{Kesadaran Halal}

Tabel 9 menunjukkan hasil uji $\mathrm{t}$ pada variabel kesadaran halal mendapatkan nilai sig. sebesar 0,000 $<0,05$ dan juga nilaikoefisien regresi yang diperoleh memiliki nilai positif sebesar 0,364 dengan nilai $t$ hitung sebesar 4,682 >t tabel sebesar 1,985. Karena nilai sig. lebih kecil dari 0,05 dan juga t hitung lebih besar dari t tabel, dapat disimpulkan jika 
kesadaran halal dapat berpengaruh secara positif dan signifikan terhadap minat beli roti halal dan hipotesis pertama diterima.

\section{Sertifikasi Halal}

Tabel 9 menunjukkan hasil uji $t$ pada variabel sertifikasi halal memperoleh nilai sign. sebesar $0,003<0,05$ dan juga nilai koefisien regresi yang diperoleh memiliki nilai positif sebesar 0,239 dengan nilai $t$ hitung sebesar 3,027 >1,985. Karena nilai sig. lebih kecil dari 0,05 dan t hitung lebih besar dari t tabel, dapat disimpulkan jika sertifikasi halal dapat berpengaruh secara positif dan signifikan terhadap minat beli roti halal dan hipotesis kedua diterima.

\section{Religiusitas}

Tabel 9 menunjukkan hasil uji t pada variabel religiusitas memperoleh nilai sig. sebesar $0,004<0,05$ dan juga nilai koefisien regresi yang diperoleh memiliki nilai positif sebesar 0,239 dengan nilai $t$ hitung sebesar 2,967 > t tabel 1,985. Karena nilai sig. lebih kecil dari 0,05 dan t hitung lebih besar dari t tabel, dapat disimpulkan jika religiusitas dapat berpengaruh secara positif dan signifikan terhadap minat beli roti halal dan hipotesis ketiga diterima.

\section{Pemasaran Halal}

Tabel 9 menunjukkan hasil uji $\mathrm{t}$ pada variabel pemasaran halal memperoleh nilai sig. sebesar $0,000<0,05$ dan juga nilai koefisien regresi yang diperoleh memiliki nilai positif sebesar 0,426 dengan nilai $t$ hitung sebesar 5,439 > t tabel 1,985. Karena nilai sig. lebih kecil dari 0,05 dan $t$ hitung lebih besar dari t tabel, dapat disimpulkan jika pemasaran halal berpengaruh secara positif dan signifikan terhadap minat beli roti halal dan hipotesis keempat diterima.

\section{Persepsi Sosial Pribadi}

Tabel 9 menunjukkan hasil uji t pada variabel persepsi sosial pribadi memperoleh nilai sig. sebesar $0,025<0,05$ dan nilai koefisien regresi memiliki nilai positif sebsar 0,177 dengan nilai t hitung sebesar 2,278 $>\mathrm{t}$ tabel 1,985. Karena nilai signifikansi ebih kecil dari 0,05 dan t hitung lebih besar dari $t$ tabel, dapat disimpulkan jika persepsi sosial pribadi berpengaruh secara positif dan signifikan terhadap minat beli roti halal dan hipotesis kelima diterima.

\section{PEMBAHASAN}

Variabel kesadaran halal berpengaruh positif dan juga signifikan terhadap minat beli pada produk roti halal. Hal ini menujukkan jika semakin baik kesadaran halal yang dimiliki oleh seseorang maka akan meningkatkan niat orang tersebut untuk membeli produk halal (Putri \& Rimadias, 2019).

Variabel sertifikasi halal berpengaruh positif dan juga signifikan terhadap minat beli produk roti halal. Hal ini menunjukkan bahwa sertifikasi halal memberikan pengaruh yang positif bagi responden pada minat beli makanan roti karena sertifikasi halal memberikan suatu jaminan akan kualitas produk 
kepada konsumen ketika mereka mengungkapkan keinginannya untuk melakukan pembelian produk halal di masa depan (Aziz \& Chok, 2013).

Variabel religiusitas berpengaruh positif serta signifikan pada minat beli konsumen muslim akan produk roti halal. Hal ini dikarenakan ketika seorang muslim diwajibkan untuk mengonsumsi makanan halal dan mencegah dirinya untuk mengonsumsi yang haram itu merupakan sebuah bentuk ketaatannya terhadap agama yang mereka imani. Sehingga ketika tingkat keimanan seseorang semakin tinggi, maka akan meningkatkan minat orang tersebut untuk membeli roti halal. Namun sebaliknya, apabila tingkat keimanan seseorang semakin rendah, maka akan semakin rendah pula minat orang tersebut untuk membeli roti halal.

Variabel pemasaran halal berpengaruh positif dan juga signifikan pada minat beli konsumen muslim akan produk roti halal. Hal ini membuktikan jika efek pemasaran halal yang dilakukan oleh produsen seperti promosi, iklan, merek dan harga berpengaruh terhadap minat beli konsumen terhadap produk roti halal. Pemasaran dan promosi yang berhubungan dengan produk makanan halal mampu mengarahkan konsumen kepada kesadaran halal karena rancangan yang berhubungan dengan kesadaran halal merupakan salah satu dari seluruh tujuan pemasaran dan juga para konsumen muslim masih mempertimbangkan agama mereka dalam mengonsumsi makanan halal (Fitria, Hermawan, \& Asnawi, 2019)

Variabel persepsi sosial pribadi berpengaruh positif dan signifkan terhadap minat beli konsumen muslim pada produk roti halal. Minat beli seorang konsumen dapat timbul karena adanya tekanan baik itu sosial maupun pribadi. Hal ini dikarenakan pengaruh dari diri sendiri dan lingkungan sosial konsumen seperti lingkungan pekerjaan, pertemanan, keluarga dan berdampak pada kontrol perilaku pribadi konsumen terhadap minat membeli produk makanan halal (Awan, et al, 2015).

\section{SIMPULAN}

Beberapa merek roti yang ada di Kota Semarang seperti SR, SHB, HB, MRB, VB, BL, dan RB sudah mengantongi sertifikat halal dari MUI. Sedangkan merek roti $\mathrm{FB}$, JD, dan BT hingga saat ini belum mempunyai sertifikat halal dari MUI. Faktor kesadaran halal, sertifikasi halal, religiusitas, pemasaran halal, dan persepsi sosial pribadi memiliki pengaruh yang positif dan juga signifikan terhadap minat beli akan produk roti halal. Faktor pemasaran halal merupakan salah satu variabel yang memiliki pengaruh paling kuat terhadap minat beli roti halal dibandingkan dengan faktor-faktor lain yang ada pada penelitian ini.

\section{DAFTAR PUSTAKA}

Achmat, Z. 2015. Theory of Planned Behavior Masihkah Rele. Academiaedu, $1-26$.

Azam, A. 2016. An empirical study on non-Muslim's packaged halal food manufacturers: Saudi Arabian consumers' purchase intention. Journal of 
Islamic Marketing, 7(4), 441-460.

Aziz, Y. A., \& Chok, N. V. 2013. The Role of Halal Awareness, Halal Certification, and Marketing Components in Determining Halal Purchase Intention Among Non-Muslims in Malaysia: A Structural Equation Modeling Approach. Journal of International Food and Agribusiness Marketing, 25(1), 1-23.

BPS. 2017. Rata-Rata Pengeluaran per Kapita Sebulan di Daerah Perkotaan Menurut Golongan Pengeluaran per Kapita Sebulan 2013-2017. Retrieved from www.bps.go.id

BPS. 2018. Penduduk Menurut Agama, Jenis Kelamin dan Kabupaten/Kota Hasil Sensus Penduduk Tahun 2010. Retrieved from https://jateng.bps.go.id/statictable/2015/02/09/791/pendudukmenurut-agama-jenis-kelamin-dan-kabupaten-kota-hasil-sensuspenduduk-tahun-2010.html

Faturohman, I. 2019. Faktor yang Mempengaruhi Minat Beli terhadap Makanan Halal . Studi pada Konsumen Muslim di. Jurnal Polban, 10, 882893.

Fitria, M. R., Hermawan, A., \& Asnawi, Y. H. 2019. the Effect of Halal Awareness, Halal Certification and Halal Marketing Toward Halal Purchase Intention of Fast Food Among Muslim Millenials Generation. Russian Journal of Agricultural and Socio-Economic Sciences, 90(6), 7683.

Ghozali, I. 2011. Aplikasi Analisis Multivariate dengan Program IBM SPSS 19 (edisi 7). Semarang: Badan Penerbit Universitas Diponegoro.

Ghozali, I. 2013. Aplikasi Analisis Multivariate dengan Program IBM SPSS 21 (edisi 7). Semarang: Badan Penerbit Universitas Diponegoro.

Mahyarni. 2013. Sebuah Kajian Historis tentang Perilaku. Jurnal El-Riyasah, $4(1), 13-23$.

MUI, H. 2014. Titik Kritis Kehalalan Bakery. Retrieved from https://www.halalmui.org/mui14/main/detail/titik-kritis-kehalalanbakery\#

Muliasari, R. M., \& Rachmina, D. 2013. Keputusan Pembelian dan Sikap Konsumen Roti (Merek Sari Roti). Jurnal Forum Agribisnis, 89-104.

Nurcahyo, A., \& Hudrasyah, H. 2017. The Influence Of Halal Awareness, Halal Certification, and Personal Societal Perception Toward Purhcase Intention: A Study Of Instant Noodle Consumption of College Student In Bandung. Journal of Business and Management, 6(1), 21-31.

Nurhasanah, S., Munandar, J. M., \& Syamsun, M. 2018. Faktor-Faktor yang Mempengaruhi Minat Beli Produk Makanan Olahan Halal pada Konsumen. Jurnal Manajemen Dan Organisasi, 8(3), 250.

Putri, M. J., \& Rimadias, S. 2019. Analisis aspek penentu niat konsumen dalam membeli produk halal di indonesia (telaah pada mie ramen jepang halal). Proseding Seminar Nasional Akuntansi 2 (1), 1-12.

Republika. 2014. Hanya 304 Produk Roti dan Bahan Roti Bersertifikat Halal. Retrieved

from 
Faktor yang Mempengaruhi Minat Beli Roti Halal pada Mahasiswa Muslim

https://www.republika.co.id/berita/nasional/umum/14/03/01/n1qoz n-hanya-304-produk-roti-dan-bahan-roti-bersetifikat-halal

Sethio Ady Saputra. 2014. Efektivitas Iklan Sari Roti ( Studi Kasus Di Poris Indah ). Universitas Esa Unggul, 1-9.

Sugiyono. 2014. Metode Penelitian Kuantitatif, Kualitatif, dan Kombinasi (Mixed Methods). Bandung: Alfabeta.

Susanto, P., \& Rahmi, N. 2013. Pengaruh Diferensiasi Produk Dan Harga Terhadap Minat Beli Pada Sepeda Fixie Di Kota Padang. Jurnal Kajian Manajemen Bisnis, 2, 59-71. 
Fauziyyah Hanum dan Adityawarman

Halaman ini sengaja di kosongkan 